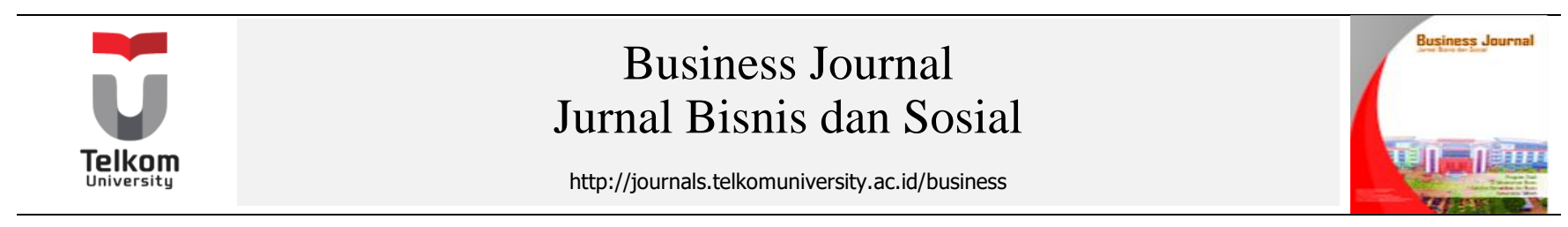

\title{
EFEKTIVITAS PENEMPATAN PEGAWAI TERHADAP PENINGKATAN KINERJA PADA BALAI KARANTINA PERTANIAN KELAS II CILEGON
}

\author{
Yuni Taniantari ${ }^{1}$, Dyah Maharani ${ }^{2}$ \\ 1,2) Prodi Adminsitrasi Negara, STIA Maulana Yusuf Banten \\ 1) tanian@gmail.com ${ }^{2)}$ dyah.maharani82@gmail.com
}

I N F O A R T I K E L

Kata Kunci

Efektivitas, Penempatan Pegawai, Kinerja

\section{A B S T R A K}

Dalam urusan penempatan pegawai yang dilakukan sebenarnya harus melalui beberapa tahapan, diantaranya tahap pertama adalah seleksi administratif dan kemudian dilanjutkan dengan seleksi melalui psikotest dan tes manajerial. Para calon pegawai yang dapat melewati tahap ini kemudian akan diseleksi berdasarkan bidang pendidikan, pengalaman kerja dan minat calon pegawai tersebut. Dari hasil seleksi tersebut calon pegawai yang direkrut kemudian akan ditempatkan sesuai bidang pendidikan dan pengalaman yang dimilikinya. Sebagai contoh, pegawai yang berlatar belakang pendidikan Sarjana Ekonomi akan ditempatkan di bidang keuangan. Penampatan pegawai sebagaimana dikemukakan oleh Prof. Dr. H. Veithzal Rivai, M.B.A., dalam bukunya Manajemen Sumber Daya Manusia Untuk Perusahaan Dari Teori Ke Praktek menyatakan bahwa penempatan pegawai/karyawan (placement) adalah mengalokasikan para pegawai/karyawan pada posisi kerja". Mengingat dalam penerimaan pegawai bukan kewenangan Balai Pertanian Karantina II Cilegon, maka penempatan pegawai yang dimaksud dalam penelitian ini adalah penempatan pegawai yang sudah ada dalam organisasi Balai Pertanian Karantina II Cilegon, dengan melalui seleksi dan uji kompetensi bagi setiap pegawai yang akan menduduki jabatan dalam setiap bagian atau bidang, selanjutnya diajukan ke Dinas Pertanian dan Kehutanan Provinsi Banten. Namun bagi pegawai /staf dalam penempatan pegawai dilakukan dengan seleksi pendidikan, pengetahuan, keterampilan dan sikap yang dimiliki oleh pegawai yang bersangkutan. Berdasarkan hasil rekapitulasi dukungan data empiris terhadap hipotesis yang dirumuskan dari Pelaksanaan Perencanaan Sumber Daya Manusia memperoleh rata-rata adalah sebesar 75,07 \% termasuk katagori "Baik", dengan kemudahan Penempatan Pegawai memperoleh hasil $76,20 \%$ juga termasuk katagori "Baik". Hal ini menunjukkan adanya indikasi korelasi positif, artinya apabila semakin tinggi tingkat pelaksanaan Perencanaan Sumber Daya Manusia akan diikuti dengan semakin tingginya kemudahan penempatan pegawai, dan begitu pula sebaliknya apabila tingkat perencanaan Sumber Daya Manusia kurang mendapat perhatian atau tidak pernah dilakukan, maka akan memperoleh kesulitan dalam menempatkan pegawai yang sesuai dengan kompetensinya..

Acknowledgment

This section contains acknowledgement for personal and/or institution, which provide support to the research (if any). 
Corresponding author at:

School of Communication \& Business, Telkom University,

Department of Business Administration

Jl. Telekomunikasi No. 1, Terusan Buah Batu, Bandung, 40257

Indonesia.

E-mail address: businessjournal@ telkomuniversity.ac.id

ORCID ID:

- $\quad$ First Author: ID of the First Author

- Second Author: ID of the Second Author

- Third Author: ID of the Third Author

- $\quad$ Fourth Author: 0000-0002-6976-7459

Published by School of Communication \& Business, Telkom University.

\section{Pendahuluan}

Era reformasi terus berjalan selama kurang lebih dua belas tahun dengan terwujudnya Otonomi Daerah yang mempunyai cita-cita ingin mewujudkan good governance sehingga memerlukan sumber daya manusia yang memiliki kompetensi dalam pencapaian tujuan organisasi.

Organisasi dalam era reformasi dan persaingan saat ini harus memiliki sumber daya manusia yang memiliki kemampuan dalam berbagai macam aspek (khususnya pengetahuan, keterampilan dan sikap) dan merumuskan strategi dalam menghadapi perubahan yang terjadi di dalam organisasinya sehingga tujuan organisasi dapat dicapai.

Seluruh tujuan organisasi yang ingin dicapai akan tergantung pada bagaimana pegawai dapat mengembangkan kemampuan baik di bidang manajerial, hubungan antarmanusia maupun teknis operasional.

Sumber daya manusia yang tangguh sangatlah dibutuhkan dalam suatu perusahaan ataupun organisasi karena era globalisasi ini telah menuntut persaingan yang semakin kompleks. Oleh karena itu, setiap organisasi tentunya akan membutuhkan orang-orang yang tangguh serta sanggup beradaptasi dengan cepat untuk setiap perubahan yang mungkin terjadi dan sanggup bekerja keras dengan dengan cara-cara yang baru khususnya dalam melaksanakan tugasnya.

Manusia sebagai pegawai dalam aktivitas organisasi pemerintah maupun swasta mempunyai peranan yang sangat penting dan berguna dalam pencapaian tujuan dan pengembangan pembangunan. Tujuan organisasi yang ditetapkan akan tercapai apabila didukung dengan sumber daya yang lengkap termasuk sumber daya pegawai yang dapat melaksanakan tugas serta dapat mengembangkan kemampuannya dengan baik.

Berkaitan dengan pelaksanaan tugas, maka prestasi kerja sangatlah ditentukan oleh kualitas seorang pegawai dalam setiap organisasi.

Manusia sebagai tenaga kerja merupakan unsur yang sangat penting bagi organisasi/perusahaan, maka pengelolaan sumber daya manusia harus dilakukan secara profesional agar terwujud keseimbangan antara kebutuhan akan kemampuan sumber daya 
manusia sebagai pegawai dengan tuntutan organisasi. Keseimbangan tersebut merupakan kunci utama agar organisasi dapat berkembang secara produktif. Penempatan pegawai yang tidak tepat akan berpengaruh terhadap produktivitas organisasi sehingga perlu diadakannya pencocokan antara keterampilan, pengetahuan dan jabatan pekerjaan.

Balai Karantina Pertanian Kelas II Cilegon merupakan salah satu bagian dari Dinas Pertanian dan Peternakan Provinsi Banten mempunyai tugas pokok mencegah tersebarnya hama penyakit hewan karantina dan organisme pengganggu tumbuhan karantina dari masuk dan keluar Wilayah Republik Indonesia serta mencegah tersebarnya dari suatu area ke area lain. Dalam melaksanakan tugas pokok dan fungsinya didukung dengan sumber daya yang tersedia, termasuk sumber daya manusia pegawai sebanyak 60 orang yang penempatannya masih belum sesuai dengan kemampuan pengetahuan, keterampilan dan sikap serta pengalaman dari pegawai yang bersangkutan. Sesuai dengan tugas pokok dan fungsinya, maka pegawai di lingkungan Balai Pertanian Karantina II Cilegon penemptannya masih menggunakan dan melihat pengalaman belum komprehensif disesuaikan dengan pendidikan, soft skill yang dimiliki, dan sikap dari pegawai itu sendiri.

Untuk itu kiranya sangat perlu melaksanakan penempatan pegawai agar sesuai dengan kompetensinya sehingga akan timbul motivasi, semangat, prestasi serta kepuasan kerja pegawai. Dengan demikian organisasi akan terus berkembang dan mencapai tujuan dengan efektif dan efisien.

Dalam urusan penempatan pegawai yang dilakukan sebenarnya harus melalui beberapa tahapan, diantaranya tahap pertama adalah seleksi administratif dan kemudian dilanjutkan dengan seleksi melalui psikotest dan tes manajerial. Para calon pegawai yang dapat melewati tahap ini kemudian akan diseleksi berdasarkan bidang pendidikan, pengalaman kerja dan minat calon pegawai tersebut. Dari hasil seleksi tersebut calon pegawai yang direkrut kemudian akan ditempatkan sesuai bidang pendidikan dan pengalaman yang dimilikinya. Sebagai contoh, pegawai yang berlatar belakang pendidikan Sarjana Ekonomi akan ditempatkan di bidang keuangan.

Penampatan pegawai sebagaimana dikemukakan oleh Prof. Dr. H. Veithzal Rivai, M.B.A., dalam bukunya Manajemen Sumber Daya Manusia Untuk Perusahaan Dari Teori Ke Praktek menyatakan bahwa penempatan pegawai/karyawan (placement) adalah mengalokasikan para pegawai/karyawan pada posisi kerja”, (2013:198).

Mengingat dalam penerimaan pegawai bukan kewenangan Balai Pertanian Karantina II Cilegon, maka penempatan pegawai yang dimaksud dalam penelitian ini adalah penempatan pegawai yang sudah ada dalam organisasi Balai Pertanian Karantina II Cilegon, dengan 
melalui seleksi dan uji kompetensi bagi setiap pegawai yang akan menduduki jabatan dalam setiap bagian atau bidang, selanjutnya diajukan ke Dinas Pertanian dan Kehutanan Provinsi Banten. Namun bagi pegawai /staf dalam penempatan pegawai dilakukan dengan seleksi pendidikan, pengetahuan, keterampilan dan sikap yang dimiliki oleh pegawai yang bersangkutan.

Upaya menempatkan pegawai sesuai dengan pengetahuan, keterampilan, sikap dan pengalaman terus dilakukan, walaupun dalam kenyataannya masih terdapat berbagai kendala yang penulis klasifikasikan sebagai gejala masalah, sebagaimana penulis ketahui saat melaksanakan pra-penelitian, sebagai berikut: (1) Penempatan pegawai kurang sesuai dengan bidang Pendidikan, Sehingga pegawai kurang memiliki hasil kerja yang baik, (2) Kurang adanya teguran dari pimpinan kepada pegawai yang lalai dalam bekerja, sehingga pegawai kurang memiliki Inisiatif tinggi dalam hal penanganan masalah-masalah yang timbul, (3) Kurang memperhatikan usia produktif dalam penempatan pegawai.

Sehingga pegawai tersebut kurang dapat menyesuaikan antara cara kerja serta situasi kerja yang ada. Berdasarkan uraian diatas maka penulis melakukan penelitian dengan judul

\section{"EFEKTIVITAS PENEMPATAN PEGAWAI TERHADAP PENINGKATAN KINERJA PEGAWAI PADA BALAI KARANTINA PERTANIAN KELAS II CILEGON".}

\section{Tinjauan Pustaka}

Sebagaimana yang dikemukakan oleh Mangkunagara dalam bukunya Manajemen Sumber Daya Manusia Perusahaan, mengemuka-kan pengertian manajemen sumber daya manusia adalah sebagai berikut: "Manajemen Sumber daya Manusia adalah suatu pengelolaan dan pendayagunaan sumber daya yang ada pada individu (pegawai). Pengelolaan dan pendayagunaan tersebut dikembangkan secara maksimal di dalam dunia kerja untuk mencapai tujuan organisasi dan pengembangan individu pegawai”, (2009: 2).

Sementara Sedarmayanti dalam bukunya Manajemen Sumber Daya Manusia Reformasi Birokrasi dan Manajemen Pegawai Negeri Sipil, mengemukakan tentang pengertian Manajemen Sumber Daya Manusia, sebagai berikut:

"Manajemen Sumber Daya Manusia adalah kebijakan dan praktik menentukan aspek "manusia" atau sumber daya manusia dalam posisi manajemen, termasuk merekrut, menyaring, melatih, memberi penghargaan, dan penilaian”, (2009 : 13). Selanjutnya menurut Sedarmayanti dalam bukunya Manajemen Sumber Daya Manusia Reformasi Birokrasi Dalam Manajemen Pegawai Negeri Sipil, mengemukakan bahwa: "Manajemen 
Sumber Daya Manusia (MSDM), adalah kebijakan dan praktik memenentukan aspek "manusia" atau sumber daya manusia dalam posisi manajemen termasuk kerekrut, menyaring, melatih, memberi penghargaan dan penilaian", (2010:13).

Pengertian penempatan karyawan adalah menempatkan karyawan sesuai dengan kebutuhan dan kopetensinya. Langkah awal dalam menghasilkan sumber daya manusia yang terampil dan andal perlu adanya suatu perencanaan dalam menentukan karyawan yang akan mengisi pekerjaan yanga ada dalam organisasi baik pemerintah maupun swasta/perusahaan yang bersangkutan. Keberhasilan dalam pengadaan tenaga kerja terletak pada ketepatan dalam penempatan karyawan, baik penempatan karyawan baru maupun karyawan lama pada posisi jabatan baru.

Proses penempatan merupakan suatu proses yang sangat menentukan dalammendapatkan karyawan yang kompeten yang dibutuhkan perusahaan, karena penempatan yang tepat dalam posisi jabatan yang tepat akan dapat membantu perusahaan dalam mencapi tujuan yang diharpakan.Adapun pengertian penempatan menurut para ahli sebagaimana penulis unggah dari antara lain: http://www.psychologymania.com/ 2012/12/pengertian-penempatan-karyawan.html., sebagai berikut: Menurut Marihot T. E. Hariandja (2005) menyatakan bahwa: "Penempatan merupakan proses penugasan/ pengisian jabatan atau penugasan kembali pegawai pada tugas/ jabatan baru atau jabatan yang berbeda".

Menurut Mathis \& Jackson (2006) menyatakan bahwa: "Penempatan adalah menempatkan posisi seseeorang ke posisi pekerjaan yang tepat, seberapa baik seorang karyawan cocok dengan pekerjaanya akan mempengaruhi jumlah dan kualitas pekerjaan. Menurut B. Siswanto Sastrohadiwiryo yang dikutp oleh Suwatno (2003): "Penempatan pegawai adalah untuk menempatkan pegawai sebagai unsur pelakasana pekerjaan pada posisi yang sesuai dengan kemampuan, kecakapan dan keahliaanya”. Berdasarkan definisi yang yang dikemukakan oleh para ahli tersebut, maka dapat disimpulkan bahwa pengertian penempatan karyawan adalah kebijaksanaan sumber daya manusia untuk menetukan posisisi/jabatan seseorang.

Kegiatan penempatan pegawai dalam fungsi kepegawaian, dimulai setelah organisasi melaksanakan kegiatan penarikan dan seleksi, yaitu pada saat seorang calon pegawai dinyatakan diterima dan siap untuk ditempatkan pada jabatan atau unit kerja yang sesuai dengan kualifikasinya. Namun ternyata permasalahannya tidak sesederhana itu, karena justru keberhasilan dari keseluruhan program pengadaan tenaga kerja terletak pada ketepatan dalam menempatkan pegawai yang bersangkutan. 
Selanjutnya pengertian penempatan pegawai itu sendiri, menurut Gomes mengemukakan bahwa: "Penempatan pegawai adalah merupakan serangkaian langkah kegiatan yang dilaksanakan untuk memutuskan apakah tepat atau tidaknya seseorang pegawai ditempatkan pada posisi tertentu yang ada di dalam organisasi”. (Sumber:Download 5 april 2011pukul 21.05 pm., diunggah dari http://id.scribd.com/doc/54689601/penempatan-kerja., download, tanggal 25 Maret 2013). Menurut Hasibuan, Melayu S.P.(2002:32) bahwa penempatan pegawai adalah tindak lanjut dari seleksi, yaitu menempatkan calon pegawai/karyawan yang diterima pada jabatan/pekerjaan yang dibutuhkannya dan sekaligus mendelegasikan authority kepada orang tersebut. Sedangkan pengertian penempatan adalah penugasan kembali seorang pegawai/karyawan kepada pekerjaan barunya (Veithzal Rifai, 2005: 170). Berdasarkan beberapa pengertian di atas dapat disimpulkan bahwa pengertian penempatan pegawai adalah serangkaian langkah penugasan pegawai dalam posisi tertentu dan sesuai dengan kompetensinya.

\section{Tabel 1. Indikator Dimensi Penempatan Pegawai}

\begin{tabular}{|c|c|c|}
\hline VARIABEL & DIMENSI & INDIKATOR \\
\hline \multirow[t]{5}{*}{$\begin{array}{c}\text { Variabel Bebas } \\
\text { (Penempatan Pegawai) }\end{array}$} & 1. Prestasi Akademik & $\begin{array}{l}\text { 1) Kualifikasi Pendidikan Formal; } \\
\text { 2) Prestasi Akademik; } \\
\text { 3) Mampu memiliki keterampilan; } \\
\text { 4) Disesuaikan dengan bidang Pendidikan. }\end{array}$ \\
\hline & 2. Pengalaman & $\begin{array}{l}\text { 5) Pengalaman Bekerja; } \\
\text { 6) Mencapai kemampuan bekerja; } \\
\text { 7) Adanya teguran dari pimpinan; } \\
\text { 8) Perlu adanya masukan untuk perbaikan } \\
\text { kerja; }\end{array}$ \\
\hline & $\begin{array}{l}\text { 3. Kesehatan Fisik dan } \\
\text { Mental. }\end{array}$ & $\begin{array}{l}\text { 9) Memiliki Kesehatan jasmani; } \\
\text { 10) Memiliki kesehatan rohani. }\end{array}$ \\
\hline & 4. Status Perkawinan & $\begin{array}{l}\text { 11) Kepentingan Mutasi atau rotasi; } \\
\text { 12) Kepentingan promosi. }\end{array}$ \\
\hline & 5. Usia & 13) Memperhatikan Usia Produktif \\
\hline
\end{tabular}

Sumber: HB. Siswanto, (2005:164) 
Sebelum menguraikan pengertian manajemen kinerja secara rinci, terlebih dahulu Kata Manajemen Kinerja merupakan penggabungan dari kata manajemen dan kinerja. Manajemen berasal dari kata “to manage” yang berarti mengatur. Menurut George R Terry dalam bukunya Principles of Management, Manajemen merupakan suatu proses yang menggunakan metode ilmu dan seni untuk menerapkan fungsi-fungsi perencanaan, pengorganisasian,pengarahan dan pengendalian pada kegiatan-kegiatan dari sekelompok manusia yang dilengkapi dengan sumber daya/faktor produksi untuk mencapai tujuan yang sudah ditetapkan lebih dahulu, secara efektif dan efisien.

Menurut Veithzal Rivai dan Ahmad Fauzi mengemukakan pengertian kinerja menurut beberapa ahli adalah sebagai berikut:

1) Kinerja merupakan seperangkat hasil yang dicapai dan merujuk pada tindakan pencapaian serta pelaksanaan sesuatu pekerjaan yang diminta (Stolovitch and Keeps, 1992)

2) Kinerja merupakan salah satu kumpulan total dari kerja yang ada pada diri pekerja (Griffin, 1987)

3) Kinerja merupakan suatu fungsi dari motivasi dan kemampuan. Untuk menyelesaikan tugas atau pekerjaan seseorang harus memiliki derajat kesediaan dan tingkat kemampuan tertentu. Kesediaan dan ketrampilan seseorang tidaklah cukup efektif untuk mengerjakan sesuatu tanpa pemahaman yang jelas tentang apa yang akan dikerjakan dan bagaimana mengerjakannya (Hersey and Blanchard, 1993)

4) Kinerja merujuk kepada tingkat keberhasilan dalam melaksanakan tugas serta kemampuan untuk mencapai tujuan yang telah ditetapkan. Kinerja dinyatakan baik dan sukses jika tujuan yang diinginkan dapat tercapai dengan baik (Donelly, Gibson and Ivancevich, 1994)

5) Kinerja sebagai kualitas dan kuantitas pencapaian tugas-tugas, baik yang dilakukan oleh individu, kelompok maupun perusahaan (Schermerhorn, Hunt and Osborn, 1991)

6) Menurut (Robbins,1996), Kinerja sebagai fungsi interaksi antara kemampuan $($ Ability $=A)$, motivasi $($ motivation $=M)$ dan kesempatan $($ Opportunity $=O)$ atau Kinerja $=f(\mathrm{~A} \times \mathrm{M} \times \mathrm{O})$; artinya: kinerja merupakan fungsi dari kemampuan, motivasi dan kesempatan, (2009:39). 
Tabel 2. Indikator Dimensi Kinerja Pegawai

\begin{tabular}{|c|c|c|}
\hline VARIABEL & DIMENSI & INDIKATOR \\
\hline \multirow[t]{6}{*}{$\begin{array}{l}\text { Variabel Terikat } \\
\text { (Kinerja Pegawai) }\end{array}$} & 1. Hasil Kerja & $\begin{array}{l}\text { 1) Setiap pegawai harus memiliki hasil } \\
\text { kerja yang baik; }\end{array}$ \\
\hline & $\begin{array}{l}\text { 2. Pengetahuan } \\
\text { Pekerjaan }\end{array}$ & $\begin{array}{l}\text { 2) Setiap pegawai harus memiliki } \\
\text { pengetahuan pekerjaan; }\end{array}$ \\
\hline & 3. Inisiatif & $\begin{array}{l}\text { 3) Untuk meningkatkan kinerja pegawai, } \\
\text { harus memiliki Inisiatif tinggi dalam } \\
\text { hal penanganan masalah-masalah } \\
\text { yang timbul; } \\
\text { 4) Adanya kemampuan dan kecepatan } \\
\text { dalam menerima instruksi kerja; }\end{array}$ \\
\hline & 4. Kecekatan Mental & $\begin{array}{l}\text { 5) Setiap pegawai harus dapat } \\
\text { menyesuaikan antara cara kerja serta } \\
\text { situasi kerja yang ada; }\end{array}$ \\
\hline & 5. Sikap & $\begin{array}{l}\text { 6) Setiap pegawai harus memiliki } \\
\text { semangat kerja serta sikap positif } \\
\text { dalam melaksanakan tugas pekerjaan; }\end{array}$ \\
\hline & $\begin{array}{l}\text { 6. Disiplin Waktu dan } \\
\text { Absensi }\end{array}$ & $\begin{array}{l}\text { 7) Setiap pegawai dalam meningkatkan } \\
\text { kinerjanya harus memiliki ketepatan } \\
\text { waktu kerja; } \\
\text { 8) Setiap pegawai dalam meningkatkan } \\
\text { kinerjanya harus memiliki tingkat } \\
\text { kehadiran yang tinggi. }\end{array}$ \\
\hline
\end{tabular}

Sumber: Dr. Edy Sutrisno, M.Si., (2011:152-153).

Dengan memperhatikan pendapat para ahli, maka dapat dirumuskan bahwa pada dasarnya manajemen kinerja merupakan gaya manajemen dalam mengelola sumberdaya yang berorientasi pada kinerja yang melakukan proses komunikasi secara terbuka dan berkelanjutan dengan menciptakan visi bersama dan pendekatan strategis serta terpadu sebagai kekuatan pendorong untuk mencapai tujuan organisasi.

\section{Metode}

Metode yang digunakan dalam penelitian ini adalah metode deskriptif analisis, yaitu suatu metode penelitian yang menggambarkan gejala-gejala dan peristiwa-peristiwa yang ada pada obyek penelitian pada saat dilakukan penelitian. Metode penelitian deskriptif menurut Nazir 
(2004:54) adalah metode yang bertujuan untuk membuat deskripsi gambaran, lukisan secara sistematis, faktual dan akurat mengenai fakta-fakta, sifat-sifat serta hubungan antara fenomena yang diselidiki. Selanjutnya data dan gejala-gejala yang telah terkumpul dianalisis secara mendalam, sistematis dan logis, kemudian dibuat laporan dalam bentuk penelitian.

Teknik pengumpulan data yang digunakan oleh penulis dalam melaksanakan penelitian ini adalah :

1) Studi Kepustakaan (Library Research), adalah penelitian yang dilakukan dengan mempelajari dan membaca buku literatur yang berhubungan dengan masalah yang diteliti.

2) Penelitian Lapangan (Field Reserach), adalah penelitian yang di lakukan secara langsung kepada objek penelitian, melalui:

a. Observasi partisipatif, yaitu mengadakan penelitian dan pencatatan secara langsung semua aktivitas objek penelitian sesuai hasil yang diperoleh, dan penulis terlibat langsung dalam pelaksanaan kegiatannya;

b. Interview, yaitu melakukan wawancara langsung dengan pejabat dalam objek penelitian yang memiliki wewenang dalam memberikan informasi yang dibutuhkan.

c. Angket yaitu merupakan suatu teknik pengumpulan data yang dilakukan dengan cara menyebarkan sejumlah daftar pertanyaan atau pernyataan untuk mendapatkan jawaban dari responden.

Dalam penelitian ini Angket yang digunakan adalah tipe angket tertutup, yaitu daftar pertanyaan tertulis yang telah disediakan alternatif jawabannya dan selanjutnya dibagikan kepada responden, untuk memperoleh tanggapan secara obyektif.

Populasi sebagaimana dikemukakan oleh Prof. Dr. Sugiyono, dalam bukunya Metode Penelitian Bisnis menyatakan bahwa "Populasi adalah wilayah generalisasi yang terdiri atas obyek/subyek yang mempunyai kualitas dan karakteristik tertentu yang ditetapkan oleh peneliti untuk dipelajari dan kemudian ditarik kesimpulannya”, (2004:72). Yang menjadi anggota populasi dalam penelitian ini adalah seluruh pegawai pada Balai Karantina Pertanian II Cilegon dengan jumlah Pegawai sebanyak 60 orang (PNS dan Non PNS/TKS), terdiri dari Kepala Balai, Kepala Sub Bagian Tata Usaha, Kepala Seksi dan Staf/Pelaksana.

Untuk menentukan sampel dalam penelitian ini penulis mengacu pada pendapat Sugiono, dalam bukunya Metode Penelitian Adminiatrasi Dilengkapi dengan Metode R\&D, (2004:74).

Untuk lebih mudah dalam pembahasan penelitian ini penlis menetapkan teknik nonprobability sampling dengan pendekatan sampling jenuh artinya bahwa seluruh populasi (60 
orang) ditetapkan menjadi sample sebanyak 60 orang. Berdasarkan uraian di atas, maka jumlah sampel yang ditetapkan secara rinci tercantum dalam tabel 1.4.

Tabel 3. Populasi dan Sampel

\begin{tabular}{|l|l|l|l|l|}
\hline No & URAIAN & POPULASI & SAMPEL & KET. \\
\hline 1 & Kepala Balai & 1 & 1 & \\
\hline 2 & Ka. Sub Bagian TU. & 1 & 1 & \\
\hline 3 & Kepala Seksi & 2 & 2 & \\
\hline 4 & Staf/Pelaksana & 56 & 56 & \\
\hline & JUMLAH: & 60 & 60 & \\
\hline
\end{tabular}

\section{Hasil dan Pembahasan}

Berdasarkan hasil rekapitulasi dukungan data empiris terhadap hipotesis yang dirumuskan dari Pelaksanaan Perencanaan Sumber Daya Manusia memperoleh rata-rata adalah sebesar 75,07 \% termasuk katagori "Baik”, dengan kemudahan Penempatan Pegawai memperoleh hasil 76,20\% juga termasuk katagori "Baik”. Hal ini menunjukkan adanya indikasi korelasi positif, artinya apabila semakin tinggi tingkat pelaksanaan Perencanaan Sumber Daya Manusia akan diikuti dengan semakin tingginya kemudahan penempatan pegawai, dan begitu pula sebaliknya apabila tingkat perencanaan Sumber Daya Manusia kurang mendapat perhatian atau tidak pernah dilakukan, maka akan memperoleh kesulitan dalam menempatkan pegawai yang sesuai dengan kompetensinya. Berdasarkan hasil tersebut dapat dilihat dalam peta dimana posisinya ada dalam kondisi baik, sebagai berikut:

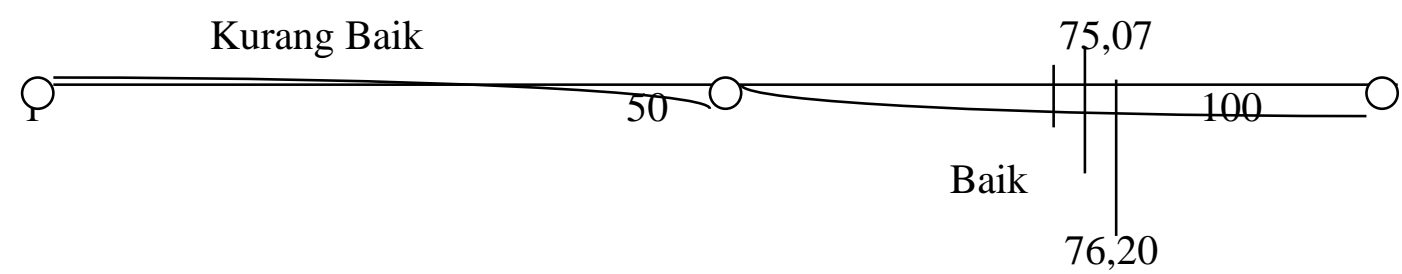

Sebagaimana telah diuraikan diatas, bahwa dalam melaksanakan Perencanaan Sumber Daya Manusia pada Balai Pertanian Karantina II Cilegon telah dilaksanakan sesuai dengan Peraturan yang berlaku serta didukung dengan teori sebagai landasan pelaksanaan penelitian. Yang dijadikan tolok ukur penelitian bahwa perencanaan sumber daya manusia berdasarkan indikator dimensi perencanaan sumber daya manusia sebagaimana dikemukakan oleh Marwansyah (2010:90) dan Edi Sutrisno (2011:40), walaupun dalam pelaksanaannya terdapat 
beberapa hambatan yang diketahui berdasarkan jawaban responden yang hanya mencapai dibawah 50\%. Untuk mengetahui beberapa hambatan tersebut, penulis uraikan di bawah ini.

1) Penempatan pegawai kurang sesuai dengan bidang Pendidikan dengan memperoleh jawaban responden sebesar 60 orang. Artinya bahwa dalam melaksanakan penempatan pegawai belum sesuai dengan pengetahuan (pendidikan) yang dimiliki pegawai. Sehingga pegawai kurang memiliki hasil kerja yang baik dengan perolehan jalaban responden sebesar 72,60\%. Kondisi ini akan berpengaruh terhadap peningkatan kinerja pegawai yang kurang optimal.

2) Kurang adanya teguran dari pimpinan kepada pegawai yang lalai dalam bekerja dengan perolehan hasil jawaban responden terhadap pertanyaan dalam angket, sebesar 69,05\%, sehingga pegawai kurang memiliki Inisiatif tinggi dalam hal penanganan masalah-masalah yang timbal, dengan perolehan hasil jawaban responden sebesar 69,05\%;

3) Kurang memperhatikan usia produktif dalam penempatan pegawai dengan perolehan nilai jawaban responden sebesar $70,45 \%$, sehingga pegawai tersebut kurang dapat menyesuaikan antara cara kerja serta situasi kerja yang ada, dengan perolehan jalaban responden sebesar $70,45 \%$.

Dengan memperhatikan seluruh hambatan di atas, masih terdapat beberapa azas penempatan pegawai yang Belem dapat dilaksanakan dengan optimal sehingga akan menurunkan tingkat kinerja pegawai. Untuk kepentingan tersebut maka diperlukan adanya usaha dari Balai Pertanian Karantina II Cilegon, agar kinerja pegawai terus meningkat.

\section{Kesimpulan}

Sebagaimana telah diuraikan diatas bahwa dalam melaksanakan Perencanaan Sumber Daya Manusia pada Balai Pertanian Karantina II Cilegon telah dilaksanakan sesuai dengan Peraturan yang berlaku serta didukung dengan teori sebagai landasan pelaksanaan penelitian. Yang dijadikan tolok ukur penelitian bahwa perencanaan sumber daya manusia berdasarkan indikator dimensi perencanaan sumber daya manusia sebagaimana dikemukakan oleh Marwansyah (2010:90) dan Edi Sutrisno (2011:40), walaupun dalam pelaksanaannya terdapat beberapa hambatan yang diketahui berdasarkan jawaban responden yang hanya mencapai dibawah $50 \%$.

1) Dalam melaksanakan penempatan pegawai dfiadakan seleksi yang baik dan benar;

2) Melakukan pengawasan melekat sehingga apabila terdapat kesalahan pimpionan dapat melakukan teguran kepada pegawai yang lalai dalam bekerja, sehingga pegawai dapat memiliki Inisiatif tinggi dalam hal penanganan masalah-masalah yang timbul; 
3) Kurang memperhatikan usia produktif dalam penempatan pegawai, sehingga pegawai tersebut kurang dapat menyesuaikan antara cara kerja serta situasi kerja yang ada;

\section{Daftar Pustaka}

Adhy Muchtar, H. Entang, 2007 Makalah Strategi Perencanaan Sumber Daya Manusia Yang Efektif, Universitas Padjadjaran Bandung.

Dwiyanto, Agus dan Kawan-kawan, 2002. Pengantar Ilmu administrasi dan Manajemen, PT.Gunung Agung, Jakarta.

Fahmi, Irham, 2010. Manajemen Kinerja, Teori Dan Aplikasi, Alfabeta, Bandung.

Hasibuan, Malayu S.P.,2001, Manajemen Sumber Daya Manusia, Bumi aksara, Bandung.

Handayaningrat, Soewarno, 2002. Pengantar Ilmu Administrasi dan Manajemen, PT. Gunung Agung, Jakarta.

Handoko, T. Hani, 1996. Manajemen Edisi 2, BPFE Universitas Gajah Mada Yogyakarta;

H.B. Siswanto, 2011. Pengantar Manajemen, Bumi Aksara, Jakarta;

Kartono, Kartini, 2001. Pemimpin dan Kepemimpinan, Rajawali Press, Jakarta.

Kencana, Inu, 2004. Sistem Administrasi Negara RI, Jilid I, PT.Bumi Aksara, Jakarta.

Masry Simbolon, Maringan, 2004. Dasar- Dasar Administrasi dan Manajemen, Ghalia Indonesia, Jakarta;

Manulang, M, 2005. Dasar-Dasar Manajemen, Gajahmada University Press, Yogyakarta.

Musanef, 2000. Manajemen Kepegawaian di Indonesia, PT.Gunung Agung, Jakarta.

Mckenna, Eugene \& Nic Beec,2000. The Essence Of Manajemen Sumber Daya Manusia, ANDI, Yogyakarta..

Mangkunegara, AA.Anwar,Prabu,2000. Manajemen Sumber Daya Manusia Perusahaan, PT. Remaja Rosdakarya, Bandung.

Manulang, M, 1988. Dasa-dasar Manajemen, Ghalia Indonesia, Jakarta.

Makmur, Syarif, 2000. Pemberdayaan Sumber daya Manusia dan Efektivitas Organisasi, Kajian Penyelenggaraan Pemerintahan Daerah, Rajawali Press, PT. RajawaliGrafindo Persada, Jakarta;

Marwansyah, 2010. Manajemen Sumber Daya Manusia Edisi ke Dua, Alfabeta, Bandung;

Nawawi, Hadari dan HM.Martini Hadiri,2004. Ilmu Administrasi, Ghalia Indonesia, Jakarta.

Nitisemito, Alex, S. Dan Rivai, Viethza, 2000. Kepemimpinan dan Perilaku Organisasi, PT.Raja Grafindo Persada, Jakarta.

Ruki Ahmad, 2003. Sistem Manajemen Kerja, PT.Gunung Agung, Jakarta;

Rivai, H. Veithzal, M.B.A.,2000. dalam bukunya Manajemen Sumber Daya Manusia Untuk Perusahaan Dari Teori Ke Praktek, Ghalia Indonesia, Jakarta;

Siagian, Sondang P, 2000. Filsafat Administrasi, PT.Gunung Agung, Jakarta.

http://tips-belajar-internet.blogspot.com/209/08/pengertian-pengawasan

http://dansite.wordpress.com/2009/04/10/definisipengertian-Motivasi-kerja/, 